\title{
Penataan Jalur Hijau di Surabaya Berdasarkan Karakteristik Jalan dan Kemampuan Visual Pengamat Studi Kasus: Jalan Mastrip Surabaya
}

\author{
Kirami Bararatin ${ }^{1}$ \\ 1Jurusan Arsitektur, Institut Teknologi Sepuluh Nopember, Surabaya, Indonesia \\ q.ramy.b@gmail.com
}

\author{
Arina Hayati ${ }^{2}$ \\ 2Jurusan Arsitektur, Institut Teknologi Sepuluh Nopember, Surabaya, Indonesia
}

\begin{abstract}
The main streets and the city entrances of Surabaya support its economic activity as well as become a potential to generate 'first impression' or image of the city for its users. In line with the city government's program, the existence of the green line in the corridor of the main streets should be remarked to develop green space. Consequently, visual objects on the green line, such as vegetation, need to meet the rules of the visual aesthetic arrangement based on the characteristics of the corridor and visual capabilities of observers. Jalan Mastrip is one of the main streets, which is crucial for the city economy and also becomes a city entrance of Surabaya. It has potential to give a positive 'first impression' for its users. However, the street condition is still beyond expectation as a city entrance. Therefore, the aim of this study is to formulate the concept of arrangement of green line in accordance with the characteristics of corridor space and visual capabilities of observers. Descriptivequalitative method is used supported by the perception of observers / respondents. Then the observations and evaluation results were analyzed to get the arrangement concept of green line of Mastrip corridor, accordance with its characteristics as Surabaya entrance corridor with industry, trade and services concept.
\end{abstract}

Keywords: first impression,green line, vegetation, arrangement

Abstrak: Surabaya memiliki sejumlah jalan utama dan jalan masuk kota dalam mendukung aktifitas perekonomiannya, sekaligus memiliki potensi menjadi 'first impression' atau cerminan wajah (image) kota bagi penggunanya. Seiring dengan program pemerintah kota, keberadaan jalur hijau di koridor jalan-jalan utama perlu diperhatikan dalam mengembangkan RTH. Oleh karena itu berbagai obyek visual pada jalur hijau tersebut seperti vegetasi, perlu memenuhi kaidah penataan estetika visual berdasarkan karakteristik jalan dan kemampuan visual pengamatnya. Jalan Mastrip (salah satu jalan utama yang berperan penting bagi roda perekonomian dan juga menjadi akses masuk kota Surabaya) memiliki potensi dalam memberikan 'first impression' yang positif bagi penggunanya. Namun kondisi yang ada sekarang masih diluar harapan. Oleh karena itu tujuan dari penelitian ini adalah merumuskan konsep penataan jalur hijau yang sesuai dengan karakteristik ruang koridor jalan dan kemampuan visual pengamat dengan menggunakan metode deskriptif-kualitatif yang didukung oleh persepsi pengamat/responden. Kemudian hasil pengamatan dan penilaian di analisis untuk mendapatkan konsep penataan jalur hijau koridor Jalan Mastrip yang sesuai dengan karakteristik jalan Mastrip yaitu koridor jalan masuk kota Surabaya dengan konsep industri, perdagangan dan jasa.

Kata Kunci: first impression, jalur hijau, vegetasi, penataan

\section{PENDAHULUAN}

Surabaya dikenal sebagai kota hijau karena memiliki komitmen yang kuat untuk membangun Ruang Tebuka Hijau (RTH) yang capaiannya telah melebihi tigapuluh persen dari luas kota Surabaya. Konsistensi ditunjukkan dengan munculnya RTH baru serta inovasi dan integrasi dengan perencanaan kota sehingga memiliki identitas kota yang menarik dan berkualitas. Pengembangan yang dilakukan tidak hanya berupa taman kota tematik, tetapi juga mengembangkan konservasi hutan bakau, RTH kampung dan jalur hijau pada jalan-jalan kota. 
Sebagai kota yang tengah gencar membangun infrastruktur jalannya, Surabaya memiliki beberapa jalan utama dan jalan masuk kota guna mendukung aktifitas perekonomiannya yang berpotensi menjadi impresi pertama atau sebagai cerminan wajah (image) kota bagi pengguna jalan seperti jalan Ahmad Yani, MERR, Jalan Mastrip. Selain penataan fasad bangunan dan street furniture, upaya pembentukan image tersebut juga dilakukan dengan penataan jalur hijau di sepanjang jalan-jalan kota.

Impresi yang baik akan muncul jika seseorang menerima respon positif dari obyek visual yang diamati sehingga obyek visual pada jalur hijau tersebut, seperti vegetasi, perlu memenuhi kaidah penataan estetika visual berdasarkan karakteristik jalan dan kemampuan visual pengamatnya. Hal ini menjadikan jalan tersebut sebagai ruang terbuka yang memiliki karakteristik pengamat spesifik yang di utamakan pada pola pengamatannya yang akan dipengaruhi oleh aktivitas pergerakan pengguna.

Seiring dengan program pemerintah kota, RTH semakin berkembang melalui keberadaan jalur hijau di koridor jalan-jalan utama kota. Vegetasi di jalur hijau dan beberapa tempat sebagai obyek utama pengisi RTH telah ditata dengan baik seperti pada koridor Jalan Ahmad Yani dan MERR, namun di beberapa tempat masih belum dilakukan seperti pada jalan Mastrip, padahal jalan Mastrip merupakan salah satu jalan yang berperan penting bagi roda perekonomian kota Surabaya dan juga menjadi akses masuk dari dua wilayah sekaligus, yaitu Kabupaten Sidoarjo dan Kabupaten Gresik sehingga potensi jalan Manstrip perlu dikembangkan dan ditingkatkan karena posisinya yang berada di wilayah perbatasan tersebut serta dapat memberikan 'first impression' bagi pengguna jalan ketika masuk ke kota Surabaya. Oleh karena itu, tujuan dari penelitian ini adalah merumuskan konsep arahan penataan jalur hijau yang sesuai dengan karakteristik ruang koridor jalan dan kemampuan visual pengamat.

\subsection{Jalan sebagai pembentuk citra kota}

Isolasi atau pemisahan stimuli visual dalam perencanaan dan perancangan lingkungan dapat menyebabkan pembentukan lingkungan visual yang asing bagi pengguna di kehidupan nyata seperti pernyataan Rapoport (1977) tentang lingkungan pada koridor jalan, bahwa stimuli visual pada perancangan. Stimulasi ini menekankan pada aspek pengalaman yang mampu menarik minat penggunanya dan membangkitkan gairah untuk mengeksplorasi lingkungannya sehingga merasa nyaman dan menjadi bagian yang tidak terpisahkan dari lingkungan tersebut. Jika kondisi lingkungan tersebut dianggap baik dan mampu mengakomodasi kebutuhan pengguna, [maka] seseorang akan tertarik untuk melibatkan diri di dalamnya (Steele,1981).
Jalan raya sebagai salah satu wujud ruang terbuka kota memiliki berbagai fungsi diantaranya fungsi ekonomi, sosial, dan estetik. Fungsi estetik berkaitan dengan bagaimana jalan tersebut dapat membentuk persepsi positif bagi pengguna melalui elemen-elemen visual yang dapat memberikan kenyamanan dan pengalaman visual yang menyenangkan. Dengan fungsi estetis tersebut, jalan memiliki peranan penting dalam membentuk persepsi seseorang terhadap struktur atau image sebuah kota. Jika jalan-jalan kota hidup, kota tersebut akan menarik, begitupun sebaliknya jika jalan-jalannya menjemukan, kota juga akan tampak menjemukan (Jacobs dalam Broadbent, 2001). Hal ini karena manusia mengamati rangkaian obyek visual di sepanjang jalur sirkulasi yang kemudian menambah nilai pengalaman dan pemahamannnya akan ruang kota.

\subsection{Vegetasi sebagai obyek pembentuk jalur hijau jalan}

Koridor jalan merupakan ruang memanjang yang dibatasi oleh elemen berupa dinding, atap, dan lantai. Elemen dinding merupakan elemen bidang vertikal yang memanjang di kedua sisi koridor. Elemen dinding pada koridor jalan dapat berupa vegetasi di jalur hijau yang berjajar di sepanjang sisi-sisi koridor sehingga membentuk bidang vertikal yang menerus. Tanaman dan bangunan selalu memiliki keterkaitan yang spesial karena keduanya memberikan standar dan cara dalam memaknai sebuah lansekap. Dalam peracangan lansekap saat ini, keberadan tanaman dapat memperkaya nilai arsitektural sebuah bangunan, begitupun sebaliknya bangunan menunjukkan kualitas arsitektural sebuah tanaman. (Cullen, 1978)

Kehadiran tanaman dalam sebuah lingkungan memberikan kepuasan psikologis yang mendalam bagi penghuninya. Tanaman memiliki banyak kegunaan dalam kaitannya dengan jalan, yaitu (McClusky, 1992):

1. Fungsi ekologis, seperti menyerap gas beracun, mengeluarkan oksigen dan memfilter debu.

2. Fungsi teknik, seperti mencegah erosi, tameng cahaya, kontrol kebisingan, kontrol iklim, pelindung dari angin dan menjadi elemen pengarah lalu lintas.

3. Fungsi arsitektural, seperti memperkaya kualitas visual ruang jalan melaui bentuk, warna, pattern dan tekstur tanaman.

Terkait dengan aspek kualitas visual ruang koridor jalan, beberapa segi pertimbangan lebih dikaitkan dengan nilai estetikanya meskipun tanpa menghilangkan fungsi teknis yang lain. Oleh karena itu vegetasi sebagai elemen dinding koridor lebih menekankan pada penataan dari aspek: (1) bentuk dan jenis tanaman, (2) warna tanaman dan (3) peletakan/komposisi tanaman. 


\subsection{Pengaruh karakteristik jalan dan kecepatan pengamat terhadap penataan tanaman}

Pemilihan tanaman berkaitan dengan skala lahan, bentuk lahan dan juga kecepatan lalu lintas yang dikaitkan dengan perubahan pandangan pengguna jalan tersebut. Pada jalan lurus, pandangan kedepan akan bertambah dan berubah sepanjang pemandangan di sisi jalan sedangkan pada jalan yang berbelok (curved lenght), pandangan akan berubah seiring dengan perubahan tikungan. Tingkat perubahan pandangan akan bergantung pada kedekatan pandangan dan kecepatan kendaraan. Obyek yang jauh akan terlihat statis untuk beberapa lama, sedangkan obyek yang dekat akan terlihat cepat berubah dan berlalu. Deretan tanaman pada high speed road dapat diperpanjang jika dimaksudkan untuk menarik kesadaran pengemudi.

Pengalaman saat mengemudi akan banyak diperoleh jika mengurangi ruang yang tertutup atau dibatasi oleh pepohonan dan digantikan dengan ruang terbuka sehingga pandangan menjadi leluasa (McClusky, 1992) sehingga kemonotonan koridor jalan dapat menimbulkan efek negatif secara psikologis. Hal tersebut dapat diminimalisir dengan kehadiran tanaman dengan komposisi yang beragam (McClusky dalam Subadyo, 2003). Komposisi yang paling menarik pada penatan tanaman pada umumnya apabila variasinya cukup kaya yang terjalin menjadi satu kesatuan yang serasi (Arnold dalam Subadyo, 2008).

Keterkaitan antara kecepatan dan skala sangat signifikan bagi semua aspek dalam merancang sebuah jalan. Semakin tinggi kecepatan, semakin lebar jalan yang dibutuhkan, semakin besar jari-jari kurva tikungan, semakin lama garis-garis pandangan, dan tanaman ditempatkan semakin jauh dari sisi jalan. Semakin rendah kecepatan, semakin dekat tanaman ditempatkan ke sisi jalan dan tanaman semak juga dapat ditambahkan sebagai protective barrier dan didekatkan di sisi jalan (McClusky, 1992). Persepsi seseorang atau kemampuan menangkap informasi lingkungan secara visual dalam kondisi bergerak akan berbeda antara kecepatan yang satu dengan yang lain. Pada koridor jalan jenis kecepatan dapat dibagi sebagai berikut (Ching, 1979:96):

1. Kecepatan pejalan kaki. Pedestrian memiliki kebebasan bergerak yang tidak terbatas. Mereka membutuhkan perubahan visual yang cepat, menarik, beraneka ragam, dan impresif.

2. Kecepatan kendaraan. Kebebasan bergerak semakin terbatas. Menurut penelitan Hamilton dan Thurstone, semakin tinggi kecepatan bergerak maka konsentrasi pengamat bertambah, sudut pandangan mengecil atau semakin fokus sehingga detail-detail yang paling dekat terlihat memudar sehingga membutuhkan bentukan dan lengkunganlengkungan yang mengalir bebas dan artikulasiperulangan yang lebar, selaras dengan irama jalannya kendaraan (McKluskey, 1992).

Tiap individu sudut visi sekitarnya berbeda-beda menurut umurnya, dimana sudut yang terkecil tercatat sampai dengan $40^{\circ}$, bahkan untuk individu dengan usia diatas 60 tahun sudut visi tersebut cenderung mengecil lagi. Demikian juga dengan kecepatan kendaraan akan membawa pengaruh yang nyata pada besaran sudut visi sekitar, dimana fokus pandangan tersebut menghasilkan hubungan seperti: (1) kecepatan $40 \mathrm{~km} / \mathrm{jam}$ memiliki fokus 180 meter; (2) kecepatan $65 \mathrm{~km} / \mathrm{jam}$ memiliki fokus 360 meter; dan (3) kecepatan $100 \mathrm{~km} / \mathrm{jam}$ memiliki fokus 600 meter sedangkan pengaruh kecepatan terhadap sudut pandang daerah sekitar menyebabkan sudut menjadi lebih kecil, yakni: (1) kecepatan $40 \mathrm{~km} / \mathrm{jam}$ memiliki sudut pandang horisontal $100^{\circ}$; (2) kecepatan 65 $\mathrm{km} / \mathrm{jam}$ memiliki sudut pandang horisontal $65^{\circ}$; dan (3) kecepatan $100 \mathrm{~km} / \mathrm{jam}$ memiliki sudut pandang horisontal $40^{\circ}$. Dengan dasar teori visi sekitar ini maka perletakan rambu-rambu, papan petunjuk dan pohonpohon pada ruang koridor jalan di luar kota harus dibedakan dengan perletakannya pada ruang koridor jalan di dalam kota. Selain itu pemecahan terhadap masalah gangguan visual juga dapat didekati dengan teori sudut pandang diatas.

\section{METODE PENELITIAN}

Berdasarkan jenisnya penelitian ini tergolong kedalam penelitian deskriptif-kualitatif karena dalam prosesnya hasil observasi atau pengamatan berupa penjabaran secara rinci kualitas visual obyek studi disusun secara deskriptif dengan memaparkan dan menyajikan kondisi faktual terkait kualitas visual elemen-elemen pembentuk jalur hijau jalan yang dalam hal ini adalah elemen softscape (vegetasi).

Hasil pengamatan berupa informasi dibantu oleh kuisioner sebagai data pendukung terkait persepsi dari pihak lain dengan tujuan agar pengamatan dapat bersifat obyektif. Karena dalam penelitian ini melibatkan persepsi seseorang sebagai pengamat atau pengguna maka dengan melakukan penelitian kualitatif, fakta yang ada di lapangan dapat terungkap dan terintegrasi, serta memiliki kapasitas untuk dipahami secara sistematis dan fleksibel dalam prosedur penelitiannya (Groat \& Wang, 2002). Kemudian dengan melakukan kuantifikasi data kualitatif maka fakta-fakta yang ada di lapangan dapat dipertanggungjawabkan secara numerik dan lebih terstruktur.

Responden termasuk ke dalam Convenience Sampling (Accidental sampling/Captive Sample) atau sample yang dipilih berdasarkan pertimbangan kemudahan. Seseorang diambil sebagai sampel karena alasan kebetulan ada di lokasi studi atau peneliti mengenal orang tersebut (Sugiarto, 2000). Jumlah responden sebanyak 40 orang yang terdiri dari 
pengguna jalan, masyarakat setempat dan kelompok yang berkompeten. Beberapa variabel dari kondisi visual elemen pembentuk jalur hijau yang akan diobservasi berdasarkan hasil sintesa pustaka dapat dilihat pada tabel 3.1

Tabel 3.1 Variabel penelitian

\begin{tabular}{|c|c|c|}
\hline Variabel & Deskripsi & Indikator \\
\hline Bentuk & $\begin{array}{l}\text { Sifat visual yang } \\
\text { ditampilkan oleh } \\
\text { masing-masing } \\
\text { jenis vegetasi. }\end{array}$ & $\begin{array}{l}\text { Kesesuaian } \\
\text { dengan fungsi } \\
\text { estetis dan } \\
\text { teknis, variasi, } \\
\text { dominasi, } \\
\text { kuantitas }\end{array}$ \\
\hline Warna & $\begin{array}{l}\text { Corak yang } \\
\text { dihasilkan oleh } \\
\text { beberapa bagian } \\
\text { dari tanaman } \\
\text { seperti daun, } \\
\text { bunga, batang. }\end{array}$ & $\begin{array}{l}\text { Komposisi } \\
\text { estetis, keunikan, } \\
\text { variasi, kuantitas }\end{array}$ \\
\hline Penempatan & $\begin{array}{l}\text { Peletakan } \\
\text { vegetasi yang } \\
\text { dapat } \\
\text { memberikan } \\
\text { makna visual bagi } \\
\text { pengamat baik } \\
\text { sebagai elemen } \\
\text { estetis, elemen } \\
\text { teknis maupun } \\
\text { elemen ekologis } \\
\text { berdasarkan } \\
\text { karakteristik jalan. }\end{array}$ & $\begin{array}{l}\text { Variasi, } \\
\text { penekanan, } \\
\text { keseimbangan, } \\
\text { keserasian, } \\
\text { kesederhanaan } \\
\text { dan irama. }\end{array}$ \\
\hline
\end{tabular}

Sumber: Analisis, 2015

Hasil pengamatan dan penilaian kemudian dianalisis dengan metode triangulasi-deskriptif berdasarkan data yang telah didapatkan baik primer (observasi) maupun sekunder (kebijakan, teori) untuk merumuskan arahan dan konsep penataan.

\section{HASIL DAN PEMBAHASAN}

Dalam tahap observasi dan penilaian terhadap kualitas jalur hijau di sepanjang jalan Mastrip, dilakukan dengan membagi lintasan kedalam tiga segmen. Jalur sirkulasi sebagai sebuah entrance dikondisikan layaknya seorang pengguna mengalami sebuah transisi suasana ruang sehingga suasana kedatangan lebih terasa. Oleh karena itu perlu ada serial vision yang merefleksikan perubahan yang dimulai dari bagian awal, tengah dan akhir.

\subsection{Karakter Fisik jalan Mastrip}

Jalan Mastrip merupakan bagian dari rangkaian jalan utama menuju pusat kota Surabaya yang dimulai dari jalan Mastrip, jalan Gunungsari hingga jalan Joyoboyo. Penelitian tidak dilakukan di seluruh panjang jalan tersebut namun hanya dilakukan pada segmen pertama yaitu jalan Mastrip karena sebagai jalur yang membentuk 'first impression' kota yang dituju.

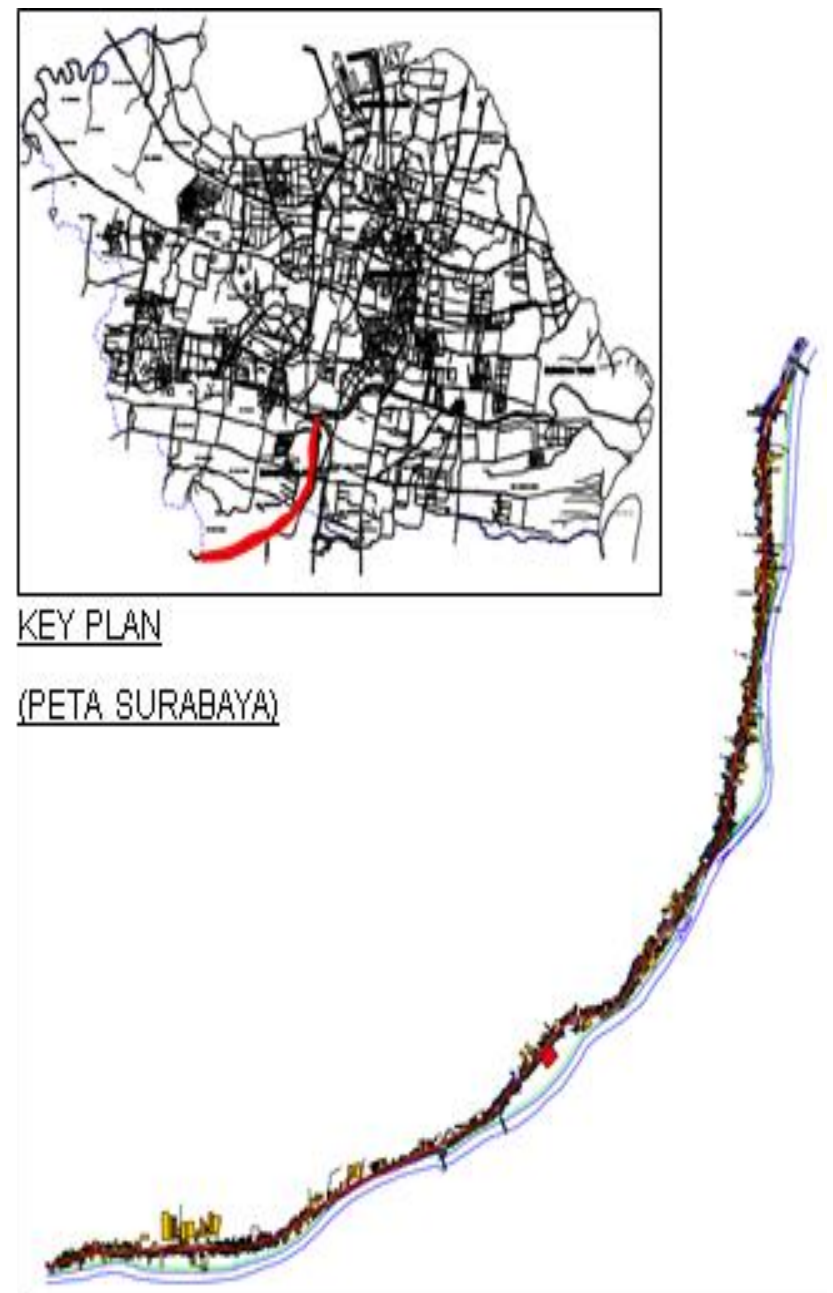

Gambar 4.1 Peta wilayah penelitian (koridor jalan Mastrip)

Jalan Mastrip - Surabaya berada di wilayah Surabaya Selatan yang termasuk dalam wilayah Perencanaan Unit Pengembangan Wiyung dengan panjang lintasan $\pm 7 \mathrm{~km}$. Pada awalnya kawasan ini dikenal sebagai kawaan pertanian, perkampungan, industri dan perumahan militer. Kemudian berdasarkan RDTRK UP Wiyung 2009-2029, pemanfaatan ruang di sisi - sisi jalan ini direncanakan untuk pengembangan perdagangan/jasa komersial. Jalan Mastrip saat ini digolongkan sebagai jalan kolektor primer sedangkan menurut rencana akan ditingkatkan menjadi jalan arteri primer. Karakteristik geografis yang dimiliki jalan Mastrip adalah letaknya yang bersebelahan dengan sungai Surabaya.

\subsection{Observasi dan Penilaian Segmen 1 \\ 3.2.1 Bentuk Observasi}

Bentuk dan ukuran tanaman bervariasi. Terdapat sekitar tiga bentuk pohon (columnar, globular, informal/menjuntai dan perdu). Sebagian vegetasi merupakan pohon besar yang mendominasi dan tajuknya menaungi hingga setengah ruang jalan. 


\section{Persepsi pengamat/responden}

Sejumlah $46.6 \%$ responden berpendapat bahwa bentuk pohon yang ada sudah memberikan visualisasi yang menarik terhadap ruang koridor jalan sedangkan $53.3 \%$ responden berpendapat sebaliknya.

\section{Penilaian}

Bentuk tanaman yang ada belum menarik secara visual dan pola penataannya juga kurang optimal sehingga tanaman yang ada tidak memiliki kontinuitas secara visual atau terkesan berdiri sendiri. Selain itu belum ada penggunaan bentuk (jenis) tanaman yang khas yang dapat memperkuat karakter koridor jalan namun perlu juga diimbangi dengan menambahkan keragaman bentuk vegetasi untuk menghindari kesan monoton.

\subsubsection{Warna}

\section{Observasi}

Hasil observasi memperlihatkan minimnya jenis pohon yang memiliki variasi warna pada bunga maupun daun. Selain itu tidak ada variasi warna yang dapat membentuk karakter ruang koridor jalan. Minimnya pemeliharaan terhadap pohon-pohon yang ada menyebabkan warna pohon/tanaman kurang terlihat optimal.

\section{Persepsi pengamat/responden}

Sejumlah 40 persen responden berpendapat bahwa warna pohon yang ada sudah memberikan visualisasi yang menarik terhadap ruang koridor jalan dan 60 persen responden berpendapat warna pohon yang sudah ada menarik secara visual.

\section{Penilaian}

Dari hasil penilaian diketahui bahwa variasi warna daun atau bunga dari vegetasi yang ada belum memberikan visualisasi yang menarik. Jenis dan jumlah pohon dengan karakter warna tertentu jumlahnya sedikit dan belum tertata. Selain itu tidak adanya pemilihan wana bunga/daun yang tematik (satu jenis warna) belum mampu memperkuat karakter ruang koridor jalan di segmen ini, namun hal ini perlu diimbangi dengan menambahkan keragaman jenis vegetasi dengan warna yang lebih heterogen untuk memberikan variasi pandangan.

\subsubsection{Penempatan Observasi}

Dari hasil observasi nampak bahwa keberadaan pohon peneduh sangat minim. Tidak ada penataan atau penempatan vegetasi yang terencana baik dari aspek pemilihan jenis tanaman maupun jarak tanamnya sehingga belum menimbulkan kontinuitas pandangan. Pohon-pohon minim perawatan sehingga fungsi teknik tanaman belum optimal. Di beberapa muka bangunan industri, tanaman sudah tertata, baik dari aspek penempatan, keragaman jenis tanaman maupun perawatannya. Selain itu pemisahan antara jalur hijau dengan jalur pejalan kaki masih belum terlihat.

\section{Persepsi pengamat/responden}

Sejumlah $61.5 \%$ responden berpendapat bahwa penempatan vegetasi yang ada sudah memberikan visualisasi yang menarik terhadap ruang koridor jalan sedangkan $38.4 \%$ responden lainnya berpendapat sebaliknya.

\section{Penilaian}

Pola penataan tanaman belum memenuhi aspek estetika sehingga kurang menarik secara visual. Namun sebelumnya dibutuhkan jalur hijau khusus yang terpisah dengan jalur pejalan kaki sehingga pola tatanan tanaman menjadi lebih jelas. Penataan pohonpohon yang memiliki bentuk/jenis yang dominan masih sangat minim sehingga diperlukan penambahan keragaman jenis tanaman yang ditata secara terencana atau membentuk pola irama yang dinamis sehingga tampilannya lebih menarik. Dengan banyaknya bangunan perdagangan atau pertokoan, keberadaan vegetasi dianggap mengganggu sehingga titik-titik tanam menjadi berkurang khususnya tanaman-tanaman berukuran besar.

Oleh karena itu dengan menyediakan jalur hijau yang jelas maka bangunan-bangunan tersebut dapat melakukan penyesuaian bukan sebaliknya. Selain memiliki fungsi estetis, tanaman tersebut juga memiliki fungsi teknis yang tidak kalah penting yaitu sebagai pengaman, penyerap polusi, kebisingan, dan peneduh. Fungsi tersebut sangat dibutuhkan mengingat karakteristik jalan Mastrip sebagai jalan kolektor primer yang sangat padat.

\subsection{Observasi dan Penilaian Segmen 2 3.3.1. Bentuk Observasi}

Bentuk dan ukuran tanaman bervariasi. Terdapat sekitar tiga bentuk pohon: columnar (palm, gelodokan tiang), globular (angsana, tanjung) dan informal/menjuntai (keres, asem). Sebagian besar vegetasi merupakan pohon besar dengan ketinggian 10 hingga 15 meter dan tajuknya menaungi hingga setengah ruang jalan.

\section{Persepsi pengamat/responden}

Sebesar $61.5 \%$ responden berpendapat bahwa bentuk pohon yang ada sudah memberikan visualisasi yang menarik terhadap ruang koridor jalan, sedangkan $38.4 \%$ responden berpendapat sebaliknya.

\section{Penilaian}

Variasi bentuk tanaman yang ada sudah memenuhi fungsi estetis maupun teknis (peneduh dan penyerap polusi). Jika dibandingkan dengan segmen 1 , terdapat lebih banyak jumlah tanaman pada segmen 2 , hanya saja penataannya perlu ditingkatkan karena pada segmen 2 belum nampak adanya tanaman khas yang dapat memperkuat karakter koridor jalan dan masih terkesan berdiri sendiri. Dilihat dari bentuk, ukuran dan jumlahnya, bentuk tanaman globular sangat mendominsai sehingga dapat memberikan potensi 
sebagai karakter ruang koridor jalan di segmen 1 , namun perlu diimbangi juga dengan menambahkan keragaman bentuk vegetasi untuk menghindari kesan yang monoton.

\subsubsection{Warna \\ Observasi}

Pada segmen 2 diketahui jenis pohon yang memiliki variasi warna pada bunga maupun daun sangat minim. Hal ini dikarenakan sebagian besar pohon di segmen 2 ini memiliki fungsi teknis (peneduh) yang sangat dominan dibandingkan dengan fungsi estetisnya sehingga keragaman warna yang membentuk karakter ruang koridor jalan masih minim.

\section{Persepsi pengamat/responden}

Sejumlah $53.8 \%$ responden yang diwawancarai berpendapat bahwa warna pohon yang ada sudah memberikan visualisasi yang menarik terhadap ruang koridor jalan sedangkan $46.1 \%$ responden berpendapat sebaliknya.

\section{Penilaian}

Variasi warna daun atau bunga dari vegetasi yang ada di segmen 2 belum memberikan visualisasi yang menarik akibat sedikitnya jumlah jenis pohon yang memiliki karakter warna tertentu serta kurang tertata dengan baik. Selain itu tidak adanya pemilihan wana bunga/daun yang tematik (satu jenis warna) berdampak pada belum menguatnya karakter ruang koridor jalan di segmen ini, namun hal ini dapat diimbangi dengan menambahkan keragaman jenis vegetasi dengan warna yang lebih heterogen untuk memberikan variasi pandangan.

\subsubsection{Penempatan \\ Observasi}

Hasil observasi terhadap aspek penempatan vegetasi menunjukkan tidak adanya penataan atau penempatan vegetasi yang terencana baik, baik dari aspek pemilihan jenis tanaman maupun jarak tanamnya. Selain itu tanaman yang tertata hanya di beberapa penggal jalan saja selanjutnya mengalami diskontinuitas sedangkan di beberapa tempat jalur hijau belum terpisah dengan jalur pejalan kaki. Pada muka bangunan komersil keberadaan tanaman sangat minim karena dianggap dapat mengganggu pandangan konsumen.

\section{Persepsi pengamat/responden}

Sebesar $36.4 \%$ responden berpendapat bahwa penempatan vegetasi yang ada sudah memberikan visualisasi yang menarik terhadap ruang koridor jalan sedangkan $61.5 \%$ responden berpendapat sebaliknya.

\section{Penilaian}

Pola penataan tanaman belum memenuhi aspek estetika sehingga kurang menarik secara visual. Namun sebelum penataan tanaman dilakukan dibutuhkan jalur hijau khusus yang terpisah dengan jalur pejalan kaki, sehingga pola tatanan tanaman menjadi lebih jelas. Selain itu penataan pohon-pohon yang memiliki bentuk/jenis yang dominan masih sangat minim, sehingga diperlukan penambahan keragaman jenis tanaman yang ditata secara terencana atau membentuk pola irama yang dinamis agar lebih menarik. Dengan banyaknya bangunan perdagangan atau pertokoan, keberadaan vegetasi dianggap mengganggu sehingga titik-titik tanam menjadi berkurang. Oleh karena itu dengan menyediakan jalur hijau yang jelas diharapkan bangunan-bangunan tersebut dapat melakukan penyesuaian.

\subsection{Observasi dan Penilaian Segmen 3 \\ 3.4.1. Bentuk \\ Observasi}

Bentuk dan ukuran tanaman yang berada pada segmen 3 bervariasi. Terdapat sekitar 2 bentuk pohon yang mendominasi: columnar (gelodokan tiang) dan globular (angsana, tanjung, mangga dan ketapang) . Sebagian besar vegetasi yang berada di segmen 3 memiliki ketinggian 5 hingga 15 meter dan tajuknya menaungi ruang jalan. Di beberapa penggal jalan terlihat adanya penggunaan tanaman perdu jenis tehtehan

\section{Persepsi pengamat/responden}

Dari 40 responden yang diwawancarai, sejumlah $41.6 \%$ diantaranya berpendapat bahwa bentuk pohon yang ada sudah memberikan visualisasi yang menarik terhadap ruang koridor jalan sedangkan 58.3\% responden lainnya berpendapat sebaliknya.

\section{Penilaian}

Bentuk tanaman yang ada di segemen 3 belum memenuhi fungsi estetis dan teknis secara optimal semisal sebagai peneduh, pengarah, penyerap polusi atau penyerap kebisingan. Pada vegetasi yang berada di segmen 3 ini juga belum terlihat adanya penataan tanaman pada jalur hijau dengan menggunakan beragam jenis bentuk dan ukuran tanaman. Pada bagian utara dari segmen 3 , bentuk tanaman didominasi oleh bentuk tanaman columnar yang berfungsi sebagai pengarah. Hal tersebut dapat disebabkan karena adanya persimpanganpersimpangan antara jalan-jalan utama sehingga elemen pengarah sangat dibutuhkan pada lokasi tersebut sedangkan pada bagian selatan segmen ini bentuk vegetasi masih memiliki kesamaan dengan segmen sebelumnya yaitu bentuk tanaman globular yang memiliki tajuk lebar.

\subsubsection{Warna \\ Observasi}

Hasil observasi terhadap warna vegetasi di segmen 3 menunjukkan minimnya jenis pohon yang memiliki variasi warna pada bunga maupun daun. Sebagian besar pohon memiliki fungsi teknis (peneduh, penyerap polusi, pengarah) yang sangat dominan dibandingkan dengan fungsi estetisnya sehingga 
keragaman warna yang membentuk karakter ruang koridor jalan masih minim.

\section{Persepsi pengamat/responden}

Dari total 40 responden yang diwawancarai, hanya $25 \%$ diantaranya yang berpendapat bahwa warna pohon yang ada sudah memberikan visualisasi yang menarik terhadap ruang koridor jalan sedangkan $75 \%$ yang lain responden berpendapat sebaliknya.

\section{Penilaian}

Variasi warna daun atau bunga dari vegetasi yang ada belum memberikan visualisasi yang menarik karena sedikitnya jenis dan jumlah pohon dengan karakter warna tertentu dan belum tertata dengan baik. Tidak adanya pemilihan wana bunga/daun yang tematik (satu jenis warna) sehingga belum mampu memperkuat karakter ruang koridor jalan di segmen 3 . Warna tanaman yang khas yang akan memberikan karakter ruang koridor jalan perlu diimbangi dengan menambahkan keragaman jenis vegetasi dengan warna yang lebih heterogen untuk memberikan variasi pandangan.

\subsubsection{Penempatan Observasi}

Dari hasil observasi mengenai aspek penempatan vegetasi diketahui bahwa penghijauan dalam bentuk pohon-pohon peneduh di sisi barat dan timur sudah tersedia namun penataannya belum menyeluruh sehingga belum menimbulkan kontinuitas pandangan. Minimnya perawatan menyebabkan fungsi teknis tanaman belum optimal. Di beberapa penggal jalan, di muka bangunan industri, penataan tanaman sudah baik, dari aspek penempatan, keragaman jenis maupun perawatannya. Penempatan tanaman yang ada pada sisi barat segmen 3 umumnya berada di dalam area bangunan, karena pada sisi ini tidak disediakan jalur hijau khusus. Tanaman yang ditempatkan di luar area bangunan berada di jalur pejalan kaki. Secara umum tidak nampak adanya penataan atau penempatan pohon-pohon atau tanaman secara terencana yang membentuk pola tatanan yang kontinyu serta harmonis. Pada muka bangunan komersil keberadaan tanaman sangat minim karena dianggap dapat mengganggu pandangan para konsumen.

\section{Persepsi pengamat/responden}

Sejumlah $41.6 \%$ responden dari 40 orang yang diwawancarai berpendapat bahwa penempatan vegetasi yang ada sudah memberikan visualisasi yang menarik terhadap ruang koridor jalan sedangkan $53.3 \%$ responden berpendapat sebaliknya.

\section{Penilaian}

Secara garis besar pola penataan tanaman di segemen 3 belum memenuhi aspek estetika sehingga kurang menarik secara visual. Namun sebelum dilakukan penataan estetika vegetasi terlebih dahulu dibutuhkan fasilitas jalur hijau khusus yang terpisah dengan jalur pejalan kaki sehingga pola tatanan tanaman menjadi lebih jelas. Selain itu mengingat penataan pohon-pohon yang memiliki bentuk/jenis yang dominan masih sangat minim maka diperlukan penambahan keragaman jenis tanaman yang ditata secara terencana atau membentuk pola irama yang dinamis sehingga lebih menarik. Dengan banyaknya bangunan perdagangan atau pertokoan, keberadaan vegetasi kerap dianggap sebagai pengganggu sehingga titik-titik tanam menjadi berkurang. Oleh karena itu dengan menyediakan jalur hijau yang jelas diharapkan bangunan-bangunan tersebut dapat melakukan penyesuaian.

\subsection{Konsep disain penataan}

Berdasarkan hasil observasi dan penilaian maka dapat dirumuskan beberapa permasalahan utama terhadap jalur hijau di sepanjang koridor jalan Mastrip yang kemudian dianalisis berdasarkan kajian pustaka untuk menghasilkan konsep desain penataan yang sesuai dengan karakteristik jalan dan kemampuan visual pengamat seperti yang terlihat pada tabel 1 dan tabel 2 serta konsep komposisi visual elemen vegetasi yang harmonis seperti pada gambar 1, gambar 2 dan gambar 3 sedangkan sekuen visual yang dibentuk oleh elemen vegetasi ditata sesuai konsep pada gambar 4 .

\subsection{Usulan disain penataan}

Berdasarkan hasil analisis perumusan arahan vegetasi maka diusulkan disain vegetasi pada segmen 1 , segmen 2 dan segmen 3 seperti pada tabel 3 . 
Tabel 1 Analisis perumusan arahan penataan komposisi dan peletakan vegetasi di jalur hijau koridor jalan Mastrip

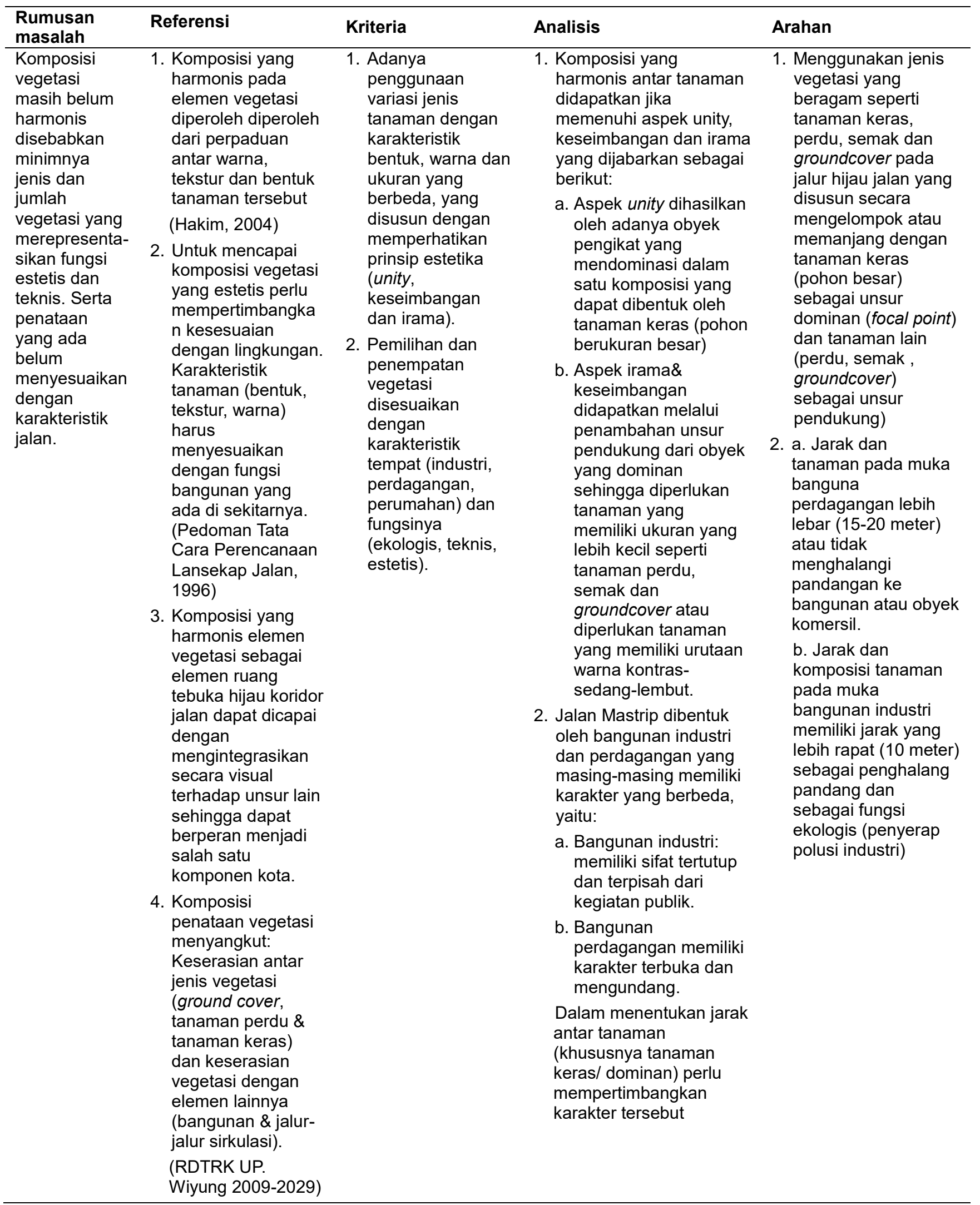




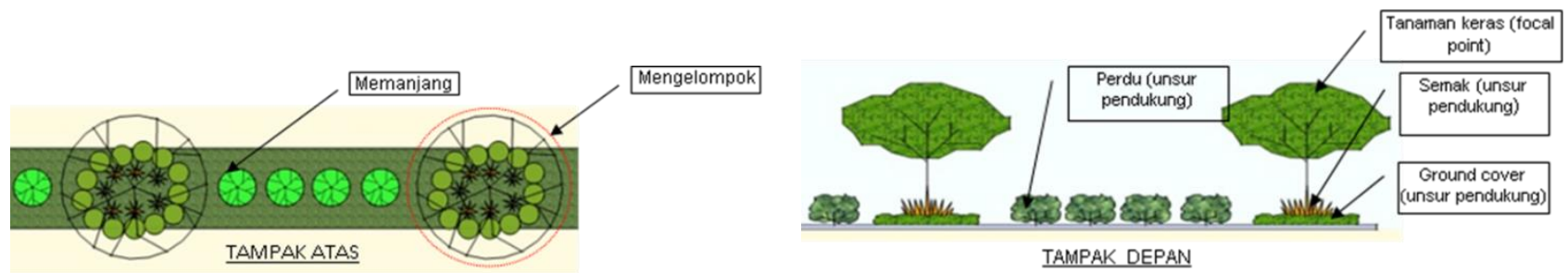

Gambar 1. Konsep penyusunan dengan prinsip unity, irama dan keseimbangan (sumber: analisis, 2015)

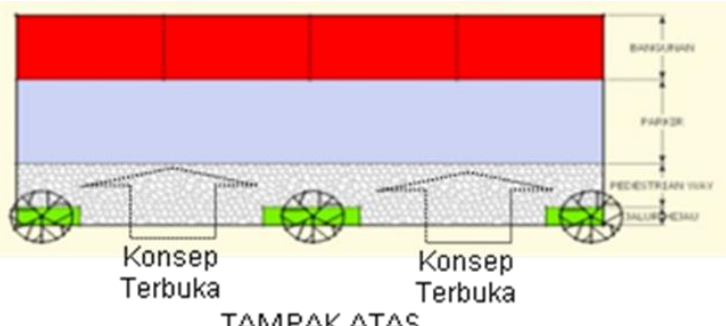

TAMPAK ATAS

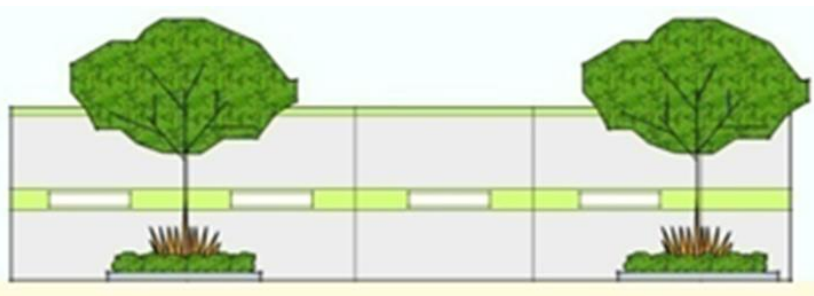

Jarak cukup ui membentuk pandangan TAMPAK DEPAN

Gambar 2. Konsep peletakan / penempatan elemen vegetasi pada muka bangunan perdagangan (sumber: analisis, 2015)

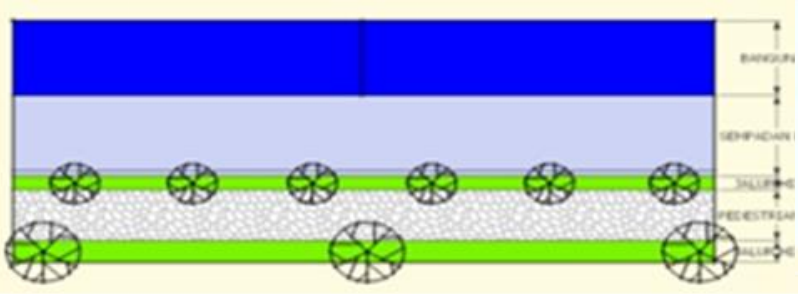

Konsep Tertutup TAMPAK ATAS

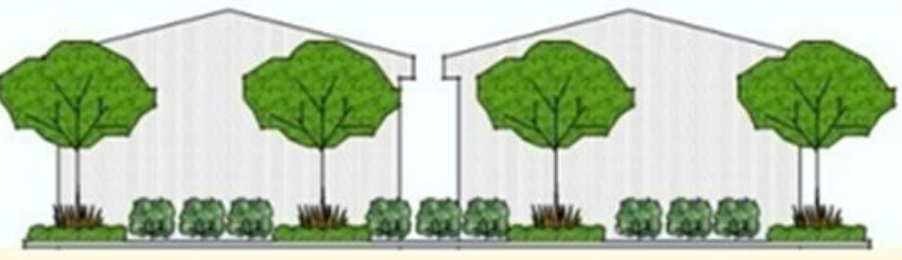

Jarak lebih rapat sebagai penghalang pandanc TAMPAK DEPAN

Gambar 3. Konsep peletakan / penempatan elemen vegetasi pada muka bangunan industri (sumber: analisis, 2015) 
Tabel 2 Analisis perumusan arahan penataan visual vegetasi jalur hijau koridor jalan Mastrip

\begin{tabular}{|c|c|c|c|c|}
\hline Rumusan masalah & Referensi & Kriteria & Analisis & Arahan \\
\hline $\begin{array}{l}\text { Belum adanya } \\
\text { tatanan perubahan } \\
\text { visual } \\
\text { (sekuen/serial } \\
\text { vision) yang } \\
\text { dibentuk oleh } \\
\text { komposisi vegetasi } \\
\text { untuk } \\
\text { merepresentasikan } \\
\text { sebuah koridor } \\
\text { jalan entrance kota. }\end{array}$ & $\begin{array}{l}\text { 1. Tanaman pada } \\
\text { koridor jalan dapat } \\
\text { dianalogikan } \\
\text { sebagai elemen } \\
\text { pembentuk ruang } \\
\text { dimana tanaman } \\
\text { dapat membentuk } \\
\text { serial visual ruang. } \\
\text { (McClusky dalam } \\
\text { Subadyo, 2008). } \\
\text { 2. Elemen vegetasi } \\
\text { memiliki fungsi } \\
\text { visual sebagai } \\
\text { pengarah dan dapat } \\
\text { menciptakan } \\
\text { suasana ruang yang } \\
\text { diinginkan. } \\
\text { 3. Pemilihan jenis } \\
\text { tanaman pada } \\
\text { koridor jalan } \\
\text { dikaitkan dengan } \\
\text { kaidah fungsi dan } \\
\text { estetika yang dapat } \\
\text { membentuk kesan } \\
\text { ruang koridor jalan } \\
\text { yang diharapkan. } \\
\text { (Pedoman Umum } \\
\text { Rencana Tata } \\
\text { Ruang Bangunan } \\
\text { dan Lingkungan) }\end{array}$ & $\begin{array}{l}\text { Adanya } \\
\text { pemanfaatan } \\
\text { keragaman } \\
\text { vegetasi yang } \\
\text { mencerminkan } \\
\text { karakter yang } \\
\text { berbeda untuk } \\
\text { menghasilkan } \\
\text { sekuen visual } \\
\text { atau serial vision }\end{array}$ & $\begin{array}{l}\text { Jalan Mastrip sebagai } \\
\text { koridor jalan masuk } \\
\text { menuju wilayah perkotaan } \\
\text { Surabaya memerlukan } \\
\text { adanya sekuens yang } \\
\text { dapat memberikan arah } \\
\text { menuju klimaks (batas } \\
\text { yang dianggap sebagai } \\
\text { gerbang perkotaan. } \\
\text { Sekuen sebuah koridor } \\
\text { jalan masuk kota menurut } \\
\text { Hakim(2004) } \\
\text { menghendaki adanya } \\
\text { perubahan kesan ruang } \\
\text { yang terbuka menuju } \\
\text { kesan ruang yang lebih } \\
\text { 'fokus'/ tertutup atau } \\
\text { sebaliknya. } \\
\text { 1. Kesan ruang terbuka } \\
\text { dapat diartikan dimana } \\
\text { batas ruang cukup } \\
\text { minim/ tidak utuh. } \\
\text { 2. Kesan ruang tertutup } \\
\text { dapat diartikan bahwa } \\
\text { batas ruang } \\
\text { membentuk ruang tiga } \\
\text { dimensional secara } \\
\text { utuh. }\end{array}$ & $\begin{array}{l}\text { Menggunakan variasi } \\
\text { jenis tanaman keras } \\
\text { (pohon besar) yang } \\
\text { berbeda pada tiap } \\
\text { segmen koridor jalan } \\
\text { Mastrip, mulai dari } \\
\text { segmen } 1 \text { hingga } \\
\text { segmen } 3 \text { dengan } \\
\text { rincian sebagai } \\
\text { berikut: } \\
\text { 1. Bagian awal } \\
\text { (segmen 1) } \\
\text { menggunakan } \\
\text { tanaman yang } \\
\text { membentuk kesan } \\
\text { ruang terbuka } \\
\text { 2. Bagian } \\
\text { pertengahan } \\
\text { (segmen } 2 \text { ) } \\
\text { menggunakan } \\
\text { tanaman yang } \\
\text { membentuk kesan } \\
\text { ruang semi } \\
\text { tertutup } \\
\text { 3. Bagian akhir } \\
\text { (Segmen } 3 \text { ) } \\
\text { menggunakan } \\
\text { tanaman yang } \\
\text { membentuk kesan } \\
\text { ruang tertutup. }\end{array}$ \\
\hline
\end{tabular}

Sumber: Analisis, 2015

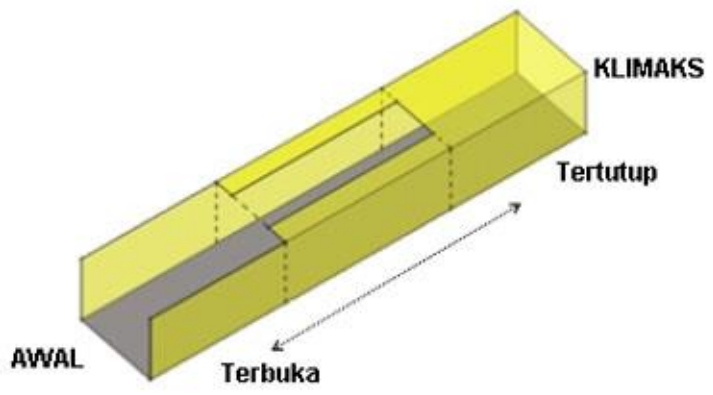

KLIMAKS

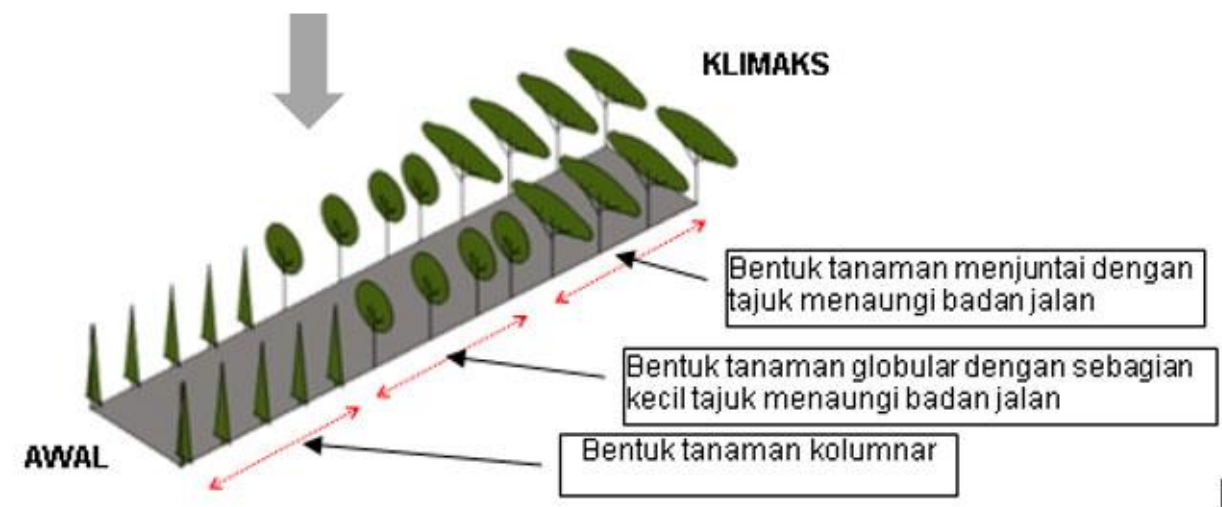

Gambar 4 Konsep sekuen visual ruang koridor jalan oleh elemen vegetasi (tanaman keras)

(sumber: analisis, 2015) 
Tabel 3 Usulan disain penataan vegetasi

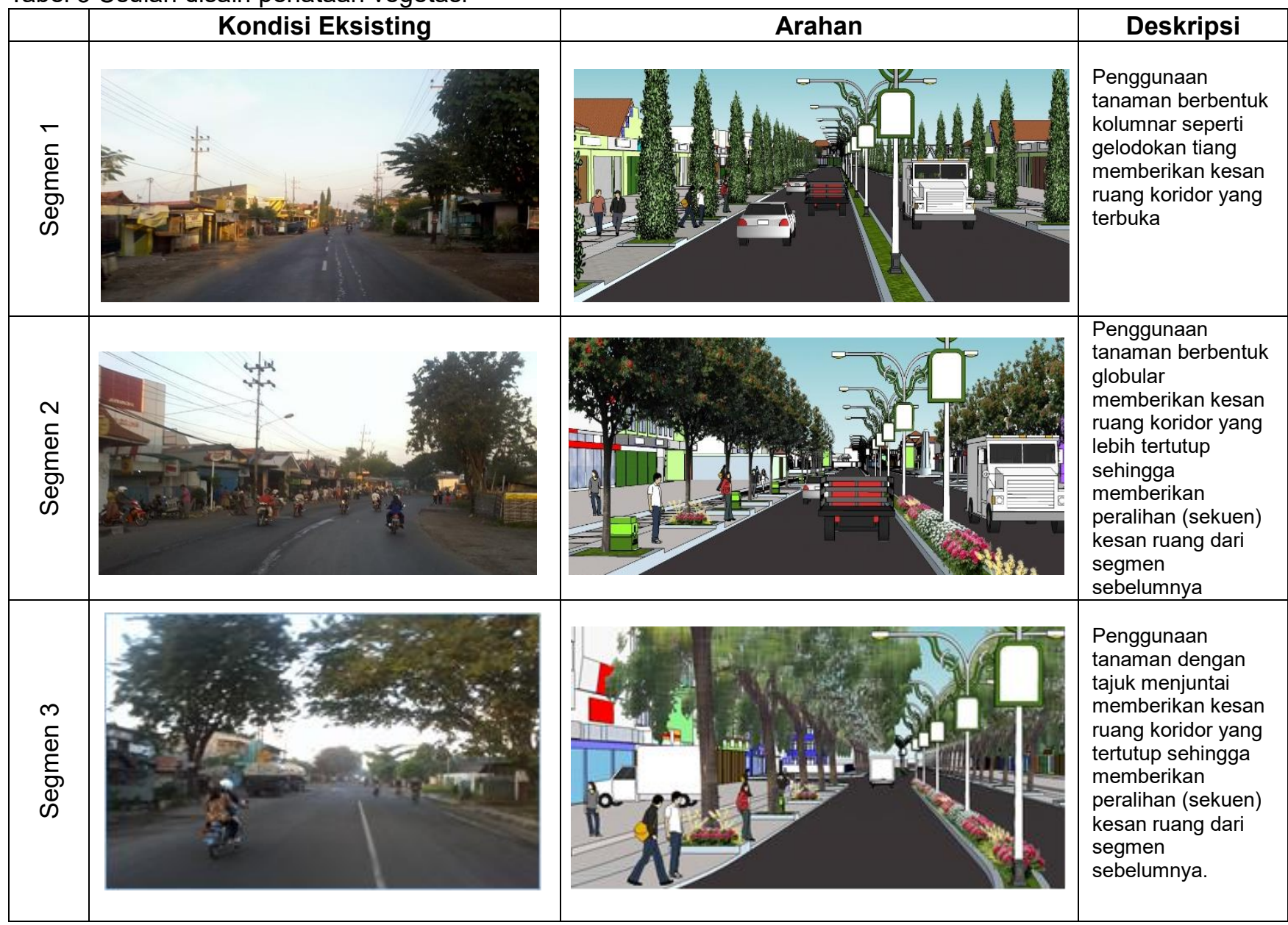

Sumber: Analisis, 2015

\section{KESIMPULAN}

1. Jalur Hijau yang dibentuk oleh vegetasi dapat memperkuat karakteristik jalan Mastrip sebagai entrance kota Surabaya melalui penataan yang membentuk sekuens visual (serial vision) seperti menggunakan variasi jenis tanaman keras (pohon besar) yang berbeda pada tiap segmen koridor jalan Mastrip, mulai dari segmen 1 hingga segmen 3 dengan rincian sebagai berikut:

a. Bagian awal (segmen 1) menggunakan tanaman yang membentuk kesan ruang terbuka

b. Bagian pertengahan (segmen 2) menggunakan tanaman yang membentuk kesan ruang semi tertutup

c. Bagian akhir (Segmen 3) menggunakan tanaman yang membentuk kesan ruang tertutup.

2. Vegetasi dibentuk oleh 3 unsur visual yaitu bentuk, warna dan penempatannya. Berdasarkan hasil pengamatan dan penilaian, ketiga unsur visual vegetasi tersebut belum memenuhi nilai estetis dan teknis karena minimnya variasi jenis tanaman yang ada di ruang koridor jalan Mastrip serta penataannnya yang tidak terencana.
Penataan tanaman hanya di beberapa titik/tidak menerus di sepanjang koridor serta tidak ada komposisi yang memperhatikan prinsip estetika (irama, kesatuan dan keseimbangan) antar jenis tanaman yang ada. Oleh karena itu dibutuhkan arahan penataan sebagai berikut:

a. Menggunakan jenis vegetasi yang beragam seperti tanaman keras, perdu, semak dan groundcover pada jalur hijau jalan yang disusun secara mengelompok atau memanjang dengan tanaman keras (pohon besar) sebagai unsur dominan (focal point) dan tanaman lain (perdu, semak, groundcover) sebagai unsur pendukung.

b. Jarak dan tanaman pada muka bangunan perdagangan lebih lebar (15-20 meter) atau tidak menghalangi pandangan ke bangunan atau obyek komersil sedangkan jarak dan komposisi tanaman pada muka bangunan industri memiliki jarak yang lebih rapat (10 meter) sebagai penghalang pandang dan sebagai fungsi ekologis (penyerap polusi industri).

3. Untuk mengakomodasi kemampuan visual pengguna berdasarkan kecepatan bergeraknya maka dalam satu jalur hijau terdapat perulangan 
komposisi tanaman mulai dari perulangan yang memiliki jarak rapat hingga jarak yang lebar. Perulangan yang rapat (setiap 2-3 meter sekali) untuk mengakomodasi kecepatan pejalan kaki sedangkan perulangan yang lebar (10-20 meter sekali) untuk mengakomodasi kecepatan pengguna kendaraan

\section{DAFTAR PUSTAKA}

Broadbent,Geoffrey (2001), Emerging Concept in Urban Space Design, Nostrand Reinhold Company, New York

Ching, DK. (1979), Architecture: Form-Space \& Order, Van Nostrand Reinhold, New York

Choguill (1996) Toward Sustainability of Human Settlements, Habitat International, Vol. 20 No 2, Elsevier Science Ltd, UK: v-viii.
Groat, Linda and Wang, David (2002), Architectural Research Methods, John Wiley \& Sons, New York McCluskey, Jim (1992), Roadform \& Townscape, Library of Congress Cataloguing, London

Rapoport, Amos (1977), Human Aspects of Urban Form, Pergamon Press

Subadyo, A. Tutut (2008), Lansekap Koridor Jalan di Perkotaan Sebagai Pembentuk Nilai Lingkungan: Kasus Kota Malang, Proposal Disertasi, Program Doktor Bidang Keahlian Arsitektur Lansekap FTSP-ITS, Surabaya

Steele, Fritz (1981), The Sense of Place, CBI Publishing Company, USA 